\title{
Razvoj e-izobraževanja in njegova vloga pri razvoju človeških virov
}

\author{
UDK: $37.014: 004.9$ \\ Boštjan Požar \\ bostjan@rra-nkr.si
}

IZVLEČEK

V kolikšni meri se je e-izobraževanje že uveljavilo kot način podajanja znanja, $v$ kolikšni meri se vključuje v obstoječe izobraževalne programe, predvsem pa kakšen je njegov potencial na področju izobraževanja, so pomembna vprašanja, ki se pojavljajo ob hitrem razvoju informacijsko-komunikacijske tehnologije (IKT). Odgovori na ta vprašanja so pomembni za načrtovanje in izvajanje izobraževalnega sistema, ki bo zadostil potrebam javnega sektorja in gospodarstva v smislu zagotovitve strokovno usposobljenega kadra, ki bo sposoben povečati inovativnost gospodarstva in s tem njegovo konkurenčnost, hkrati pa tudi učinkovitost delovanja institucij javnega sektorja. Izobraževalni sistem mora biti tesno povezan z gospodarstvom, zato mora biti uporabno usmerjen. Zagotavljati mora znanja, ki jih gospodarstvo potrebuje za pospešen razvoj. Izobraževalne možnosti so zaradi razvoja IKT bistveno večje kot $v$ preteklosti, vprašanje pa je, ali so te možnosti pri razvoju človeških virov dovolj izkoriščene.

Ključne besede: e-izobraževanje, izobraževanje, razvoj človeških virov, IKT.

\section{Uvod}

$V$ dinamičnem času, $v$ katerem živimo, formalno pridobljena znanja hitro zastarajo. Pomanjkanje ustrezno izobraženih in usposobljenih kadrov zahteva od podjetja sistematično skrb za izobraževanje in usposabljanje zaposlenih. Podjetja so zaradi razvoja informacijsko-komunikacijske tehnologije in procesa globalizacije danes pred velikimi izzivi. Ti izzivi so posledica sprememb tako na demografskem kot tudi na ekonomskem področju. Pomemben skupni imenovalec posledic teh sprememb so nenehne potrebe po novih znanjih, ki je poleg inovacijske sposobnosti opredeljeno kot ključen dejavnik konkurenčnosti gospodarstva. Ker je življenjska doba produktov vedno krajša, je za podjetje nujno stalno spreminjanje in uvajanje novih delovnih procesov, če želi obdržati položaj na trgu. To pa bodo podjetja lahko storila le z visoko usposobljenim kadrom, ki ga je treba praviloma usposobiti znotraj organizacije, saj formalno pridobljena 


\section{Boštjan Požar \\ Razvoj e-izobraževanja in njegova vloga \\ pri razvoju človeških virov}

znanja ne zadostujejo specifičnim potrebam gospodarstva, pa tudi sicer hiter tehnološki razvoj in potreba po inovacijah narekuje menedžmentu skrb za vlaganja $v$ znanje. Kakšne možnosti imajo pri tem podjetja, kako gospodarstvo obvladuje potrebe po znanju, kako se odziva na nove izobraževalne možnosti in kako perspektivne so te metode, poglejmo $v$ nadaljevanju. Uvajanje in uporaba alternativnih možnosti izobraževanja, kamor spada tudi e-izobraževanje, postaja zaradi svojih prednosti v praksi čedalje bolj pogosto.

$\checkmark$ nadaljevanju opredeljuje članek razvoj e-izobraževanja, stanje na področju e-izobraževanja danes, predvsem pa odgovarja na vprašanje, v kolikšni meri se e-izobraževanje uveljavlja kot način izobraževanja in $\vee$ kolikšni meri lahko $\vee$ prihodnosti e-izobraževanje nadomesti klasično izobraževanje $\vee$ predavalnicah. Predstavi pregled ponudbe programov e-izobraževanja in uvajanja eizobraževanja $v$ visokošolske programe, tehnološkega razvoja in $s$ tem povezanih možnosti, stroškov priprave in izvajanja e-izobraževanja, analizo potreb po e-izobraževanju $\vee$ poslovnem okolju ter drugih dejavnikov, ki vplivajo na odločitev posameznika glede vključitve $v$ e-izobraževalni program. Prav gotovo ni smiselno trditi, da bo e-izobraževanje $v$ celoti nadomestilo klasično izobraževanje, ga tako rekoč izrinilo in posledično povzročilo praznjenje predavalnic. Temu $\vee$ prid govori stanje različnih dejavnikov, kot so na primer neustreznost nekaterih vsebin za podajanje $v$ e-obliki, težavnost uvedbe e-izobraževanja v visokošolske institucije, omejene tehnološke zmožnosti posameznika, potreba po veliki stopnji motiviranosti učečih, potreba po fizičnem kontaktu med študenti, skupnemu študijskem delu, medsebojni pomoči in podobno. Na drugi strani pa hitri razvoj e-izobraževanja kaže na čedalje bolj pomembno vlogo e-izobraževanja $\vee$ obstoječih izobraževalnih programih.

\section{E-izobraževanje}

Internet kot najbolj razširjeno orodje informacijske tehnologije je korenito posegel tudi na področje izobraževanja, predvsem izobraževanja na daljavo, ki že $\vee$ osnovi temelji na posredni komunikaciji in je eden od najučinkovitejših načinov in orodij za premagovanje oddaljenosti med udeležencem izobraževanja in mentorjem (Dobnik, 2003). E-izobraževanje izhaja iz izobraževanja na daljavo, ki ima danes več sopomenk: študij na daljavo, učenje na daljavo, daljinsko izobraževanje, e-učenje, e-izobraževanje (distance learning, distance education, elearning, e-education), pri nas pa se je najbolj uveljavil izraz e-izobraževanje. Eizobraževanje temelji na uporabi IKT kot tehnologiji pri podajanju vsebine. Izobraževalni proces je podprt z IKT oziroma internetom, ki omogoča drugačno, bolj fleksibilno in predvsem interaktivno zasnovo učnih gradiv, odpira 
nove možnosti za komunikacijo med skupinami udeležencev in mentorjem ter vstopanje $v$ virtualni učni prostor na vseh lokacijah z dostopom do interneta. Gre torej za nekakšno podzvrst izobraževanja na daljavo, ki pa je že postala njegova glavna pojavna oblika.

\subsection{Začetki e-izobraževanja}

Dopisno izobraževanje, ki je bila včasih edina oblika izobraževanja na daljavo, se je s poskusi uvajanja odprtega učenja in razširjene uporabe interneta razvilo $\vee$ izobraževanje na daljavo, kot ga poznamo danes. Izobraževanje na daljavo ni novost, saj po nekaterih virih na njegove zametke naletimo že $\vee 18$. stoletju. Začelo naj bi se $z$ dopisnim izobraževanjem $v$ redko poseljenih deželah kot so Avstralija, Nova Zelandija, Kanada in ZDA, saj je takratni razvoj poštnih storitev in tiskanih gradiv omogočal, da so se ljudje $v$ odmaknjenih krajih izobraževali samostojno, ne da bi jim bilo treba obiskovati oddaljene izobraževalne ustanove. Tako pridobljeno znanje je imelo ob ustreznih evalvacijskih sistemih tudi formalno veljavo. Osnovni cilj dopisnega izobraževanja je bil dostop do izobraževanja ljudem, ki se zaradi geografske oddaljenosti, socialnih, osebnih ali vsakršnih drugih razlogov niso mogli izobraževati na običajen način. Kasneje je uporaba množičnih medijev pomnožila kanale prenašanja znanja in informacij. Z razvojem izobraževalne in informacijske tehnologije se je $v$ izobraževalne metode vključila večina novih tehnologij, kot so video in avdio zapis, televizija in informacijska tehnologija. $V$ zgodovini odprtega učenja zasledimo največji razvoj tega pristopa $\vee$ Veliki Britaniji, ki je še danes ena vodilnih držav na tem področju. Pionirji uvajanja odprtega učenja so Odprta univerza (The Open University), NEC (National Extension College - Expanding Learning Horizons) in Open Learning Foundation. $V$ zadnjih letih 20. stoletja se je pokazal viden napredek $v$ tehnologiji in vsebini e-izobraževanja. Internet nudi bistveno boljše izobraževalne možnosti in omogoča dejansko fizično ločenost med učečim in mentorjem, kar odpravlja potrebo posameznika po potovanju $\vee$ kraj, kjer se izobraževalni program izvaja. Tudi pri nas je internet ključno prispeval $k$ razmahu izobraževanja na daljavo, saj je postalo bolj opaženo in uporabljeno šele, ko je temeljilo na uporabi interneta in ga že lahko imenujemo e-izobraževanje.

\subsection{Stanje na področju e-izobraževanja danes v svetu in pri nas}

Danes se zaradi novih tehnologij in široke uporabe interneta odprto učenje in učenje na daljavo vedno manj ločujeta. Za izobraževanje na daljavo je zadnjih 


\section{Boštjan Požar \\ Razvoj e-izobraževanja in njegova vloga \\ pri razvoju človeških virov}

nekaj let značilno, da ima lastnosti tradicionalnega učenja in sloni predvsem na omrežnih storitvah. Največji in najbolj znani sistemi učenja na daljavo so del izobraževanja na daljavo, ki ga ponujajo razne šole in univerze po svetu. Dandanes so avtorjem in ponudnikom učnih gradiv na voljo številna orodja, ki se stalno razvijajo (npr. orodja za skupinsko delo ipd.). Na voljo so tudi sistemi za upravljanje izobraževanja (e-learning management systems) z aplikacijami, ki lahko podpirajo celoten izobraževalni proces neke skupine, ga upravljajo in povezujejo. Te možnosti so danes nujne, saj omogočajo večji nadzor učečih nad lastnim procesom izobraževanja. Izobraževanje na daljavo danes ponujajo univerze in komercialni ponudniki, vzpodbuja pa se tudi vseživljenjsko izobraževanje, ki ni vezano izključno na pridobivanje formalne izobrazbe. Ponudniki storitev, gradiv in orodij, ki ponujajo izobraževanje na daljavo na komercialni osnovi, so Blackboard, Apollo Group, e-learning, Cafe Mondial, EuroPACE 2000, University for Industry, Smart Force, Lightspan, ProsoftTraining, SkillSoft Corporation; Learn2.com, SmarterKids.com, VarsityBooks, Ecollege, Saba Software, Vcampus Corporation in še mnogi drugi.

V Evropi je uvajanje e-izobraževanja, za razliko od ZDA, kjer ima pobudo skoraj izključno privatni sektor, nekoliko drugače organizirano. Nekatere države, kot na primer Francija, Španija in Švedska, so ustanovile velike javno financirane organizacije. Open University iz Velike Britanije je postavila nekatere standarde za ta tip izobraževalne institucije, po katerih so se bolj ali manj zgledovali v Španiji (Universidad Nacional de Educacion a Distancia), Nemčiji (Fernuniversitaet), na Nizozemskem (Open Universiteit) in Portugalskem (Universidade Aberta). $\vee$ drugih evropskih državah prevladuje dualni model univerz, kjer e-izobraževanje dopolnjuje klasični način izobraževanja (Dinevski, 2003). Evropska komisija v svojih dokumentih (eLearning Action Plan 20042006) močno vzpodbuja razvoj e-izobraževanja $\vee$ vseh državah EU. Iz drugih dokumentov Evropske komisije je razviden cilj, da naj bi že do konca leta 2005 vse države članice poskrbele, da bi vse univerze ponujale on-line dostop študentom do izobraževalnih vsebin. Mnogi drugi programski dokumenti (eEurope+, eEurope 2005, Information Society, eLearning, eContent) in tudi resolucije Evropskega Sveta dajejo e-izobraževanju visoko prioriteto $v$ nadaljnjem razvoju EU.

$\checkmark$ Sloveniji se poleg izobraževalnih institucij (šole, univerze, komercialna izobraževalna podjetja), podjetja in javne institucije sicer zavedajo prednosti in pomembnosti take vrste izobraževanja. Svojim zaposlenim poskušajo to približati in jih spodbuditi k dodatnemu izobraževanju prek lastnih portalov, ki podpirajo izobraževanje na daljavo. Zato so ti portali $\vee$ veliki meri specializirani za zaposlene $\vee$ teh podjetjih ali ustanovah, dostopno gradivo pa je prirejeno za 
notranjo uporabo. Raba e-aplikacij za izobraževanje zaposlenih (vsa podjetja z 10 ali več zaposlenimi, brez finančnega sektorja) je $\vee$ Sloveniji procentualno bolj razširjena kot $\vee$ povprečju $\vee$ EU. $\vee$ Sloveniji uporablja e-aplikacije za izobraževanje $40 \%$ podjetij, kar jo uvršča na tretje mesto za Litvo in Ciprom. Delež takšnih podjetij se je od leta 2004 tudi povečal za 10 odstotnih točk. Sicer pa je danes težko predvideti, $\vee$ kolikšnem obsegu se bo $v$ Sloveniji e-izobraževanje razširilo in dobilo svojo pravo veljavo. Pričakovati je, da bodo glavne razvojne smernice e-izobraževanja naslednje:

- učno gradivo bo lahko dostopno prek spletnih strani organizacije, ki zaposluje posameznika;

- na voljo bodo bolj izpopolnjena orodja za upravljanje z vsebino; uporaba objektnih tehnologij bo omogočala ponudbo gradiv, ki se prilagajajo uporabnikom;

- $\quad$ sistemi za upravljanje izobraževanja bodo nadzirali in prilagajali učni program vsakemu posamezniku glede na njegovo trenutno znanje, izobrazbo, delovno mesto, želeno učno metodo in podobno. Ti sistemi bodo tudi natančno sledili uporabnikovemu napredku in ga analizirali.

\subsection{Oblike e-izobraževanja}

Izobraževanje na daljavo, kot ga poznamo danes, ima veliko oblik in izvedb, vendar je vsem oblikam skupna neka splošna arhitektura z določenimi skupnimi lastnostmi in elementi. Ponudniki izobraževalnih gradiv pripravijo eno ali večpredstavna učna gradiva. To so lahko preprosta besedila ali dinamična večpredstavna gradiva, ki vključujejo avdio, video, besedila, predstavitve in drugo. Svoja gradiva objavljajo na strežnikih, ki so prek različnih prenosnih sistemov dostopna uporabnikom in morajo podpirati ponudbo ponudnikov in uporabo uporabnikov s pomočjo uporabniških vmesnikov, ki jih imenujemo izobraževalni portali. $\vee$ tej arhitekturi je treba omeniti še vlogo tutorja, ki je $v$ bistvu učitelj oziroma inštruktor. Ta pomaga učečim pri ustrezni izbiri učnih gradiv, jih usmerja $v$ izobraževalnem procesu in ocenjuje pridobljeno znanje. Neposredno izvajana predavanja zahtevajo videokonferenčna orodja, medtem ko učna gradiva v formatu HTML in podobno, zahtevajo le spletne brskalnike. Te lastnosti oziroma zahteve določajo obliko izobraževanja na daljavo.

Ločimo sinhrono deljeno izobraževanje, asinhrono deljeno izobraževanje ter neodvisno izobraževanje. Sinhrono deljeno izobraževanje (SSL - Synchronous Shared Learning) lahko primerjamo s tradicionalnim izobraževanjem, ki ponuja neposredno izvajanje učnih gradiv $v$ realnem času. Ker so uporabniki e-izobraževanja na 


\section{Boštjan Požar \\ Razvoj e-izobraževanja in njegova vloga \\ pri razvoju človeških virov}

različnih lokacijah, se za neposredno izvajanje učnih gradiv uporabljajo različne tehnologije. Enosmerni video omogoča neposredni prenos ali prenos videoposnetka, dvosmerni video pa omogoča tudi interakcijo. Predavatelji in poslušalci so hkrati prijavljeni $v$ spletno aplikacijo, ki podpira skupno izobraževanje in tvori neko učno okolje. Taka oblika omogoča uporabnikom, da sodelujejo in tako spremenijo potek izobraževalnega procesa. Asinhrono deljeno izobraževanje (ASL-Asynchronous Shared Learning) omogoča uporabniku prilagojeno časovno uporabo učnega gradiva. Skupnega sodelovanja udeležencev ni, izobraževalni proces pa se izvaja predvsem z branjem ali $\mathrm{s}$ predvajanjem video oziroma avdio posnetka. Sodelovanje z drugimi udeleženci $\checkmark$ izobraževalnem procesu je omejeno na uporabo oglasne deske, novičarskih skupin in elektronske pošte. Zaradi omejene interakcije je zelo pomembno, da inštruktor ali učitelj lahko spremlja napredek uporabnika učnega gradiva. To vključuje spremljanje števila prijav, časovnega obsega prijave, območij, kjer je poraba časa nad- ali podpovprečna, učinkovitosti izvajanja nalog, testov in podobno. Pri neodvisnem izobraževanju (IEL-Independent e-learning) posameznik ni del skupine in praviloma nima učitelja oziroma inštruktorja. Najpogosteje je to ponudba učnih gradiv komercialnih ponudnikov, $v$ redkih primerih tudi izobraževalnih institucij, kot so na primer univerze. Kadar koli se posameznik želi dodatno ali dopolnilno izobraževati, poišče učno gradivo, ki ga zanima in ga $v$ prostem času obdela. Z ustrezno evalvacijo naj bi ponudnik ali učeči sestavil ustrezno učno gradivo iz manjših modularnih objektov, kar je tudi ena od najpomembnejših lastnosti teh sistemov. Glede na lastnosti in zahteve neodvisnega izobraževanja je ta oblika sčasoma postala najpogostejša oblika izobraževanja na daljavo. Uveljavlja se predvsem, ker se lahko uporabi "v pravem času" in je zelo prilagodljiva uporabniku.

\subsection{Standardi e-izobraževanja}

Ker je storitev relativno mlada in je množica ponudnikov e-izobraževanja precej razdrobljena, standardi, ki določajo elemente sistemov za izobraževanje na daljavo, še vedno nastajajo. Pri raziskovanju svetovnega spleta je opaziti več skupin iz poslovnega sveta, akademskih in vladnih ustanov, ki se ukvarjajo z razvojem specifikacij za sisteme izobraževanja na daljavo. Vsaka skupina se ukvarja z razvojem specifikacij elementov za sisteme izobraževanja na poseben način, vendar se kljub nastalim razlikam pri specifikacijah istih elementov, zavedajo pomembnosti sprejetja skupnega standarda za enotno pripravo, objavo, indeksiranje, razpečevanje, iskanje, kupovanje ali prodajanje učnih gradiv ter za uporabo učnih gradiv in orodij. Glavni cilji standardizacije se torej kažejo: 
1. $v$ enotnemu označevanju in opisovanju gradiv z metapodatki, s čimer bodo omogočeni preprosto iskanje in uporaba gradiv ter sledenje uporabi,; 2 . v standardizaciji granulacije gradiv, kar bo omogočalo vnovično uporabo manjših gradnikov tudi $v$ okviru drugih gradiv in 3 . $v$ bogatitvi in povečanju učinkovitosti, saj bodo učitelji lahko bolj učinkovito spremljali potek izobraževalnega procesa in temu prilagajali učna gradiva.

\subsection{Prednosti in težave e-izobraževanja}

Ker je e-izobraževanje prisotno že nekaj časa, lahko opazimo prednosti in slabosti takega izobraževanja. Pozitivna stran vzpostavljenega e-izobraževanja se kaže (Rowntree, 1992) v naslednjih koristih:

- $\quad$ koristi učečih; hitrejši dostop, boljša prilagodljivost, neodvisnost od časa in kraja, hitrost učenja, večja kakovost, možnost individualnega učenja itd.,

- $\quad$ koristi zaposlenih v izobraževalni instituciji; manj potovanj, lažje usposabljanje, več opravljenih izpitov itd.,

- koristi ponudnikov učnih gradiv; več možnosti za prilagodljivost na potrebe okolja, financiranje, nove tipe uporabnikov, možnosti dodatnega usposabljanja tutorjev, zmanjšanje neposrednih komunikacij itd.

Analiza potreb po novih načinih in oblikah izvajanja stalnega strokovnega izpopolnjevanja, ki jo je opravila Pedagoška fakulteta v Mariboru, je bila zasnovana na raziskovalni metodi anketiranja. Vzorec zajema 194 strokovnih delavcev iz dveh vzgojno-varstvenih zavodov, treh osnovnih šol, dveh srednjih in ene višje šole, ki so se odločili sodelovati v raziskavi. Izvajalca je zanimalo, kako strokovni delavci, zaposleni na področju vzgoje in izobraževanja, ocenjujejo prednosti, ki jih nudijo programi stalnega strokovnega izpopolnjevanja, zasnovani kot e-izobraževanje. Respondenti so kot najpomembnejšo prednost, ki bi jo lahko dosegli z e-izobraževanjem, prepoznali prilagodljivost časa in kraja študija oz. samostojno organiziranje časa in dela. Glede na sodobni način in tempo življenja je njihova odločitev pričakovana, saj pomeni večjo možnost za usklajevanje različnih življenjskih vlog. Najmanj pa so sodelujoči $v$ anketi poudarili možnost e-izobraževanja, da posredno razvija in krepi nove oblike pismenosti pri udeležencih izobraževanja, saj je informacijska pismenost pravzaprav eden izmed objektivnih pogojev, ki mora biti izpolnjen za učinkovito udeležbo $v$ programih e-izobraževanja.

Ker pa sta odprto učenje in učenje na daljavo, ki se danes združujeta v eizobraževanju, spremenila način učenja že mnogim ljudem in se vedno bolj 


\section{Boštjan Požar \\ Razvoj e-izobraževanja in njegova vloga \\ pri razvoju človeških virov}

širita, je treba osvetliti še nekaj težav, ki se lahko pojavijo in zavirajo razvoj eizobraževanja. Težave, ki lahko zavirajo e-izobraževanje, lahko nastanejo pri financiranju postavitve takega sistema izobraževanja, določitvi ciljne skupine, ponudbi učnih gradiv in ponudbi oblik učenja. Težave, ki se lahko pojavijo na strani učečega pa so problemi z motivacijo učečega, potreba po samostojnosti in samoorganiziranju, neustrezno računalniško znanje oz. informacijska pismenost, težave povezane z učenjem "iz monitorja", neustrezni strojna in programska oprema ter dostop do interneta oz. prepočasna internetna povezava.

\section{Razvojne možnosti e-izobraževanja}

\subsection{Ponudba e-izobraževanja in razvoj v Sloveniji}

V Sloveniji se $v$ zadnjih letih e-izobraževanje pospešeno uvaja v izobraževalni sistem in sicer kot dopolnitev klasičnemu študiju, kot samostojni študijski programi ter kot posebna izobraževanja za določene ciljne skupine. Nosilci teh programov so fakultete, nekateri zasebni in javni zavodi (Andragoški center Republike Slovenije, Zavod Republike Slovenije za šolstvo, Center za poklicno izobraževanje RS, Inštitut Jožef Stefan, Zavod MIRK, Zavod Radiotelevizija Slovenije, Doba,...), nekatera podjetja (Netis, Inter-es, IECom, Agora, Komunike,..) ter nekatere regionalne razvojne agencije (RA Sora, RRA severne Primorske, RA Sinergija, RCR Zagorje). Omeniti velja nekaj enot, ki ponujajo storitve izobraževanja na daljavo. NCP-nacionalna projektna enota za študij na daljavo na Ekonomski fakulteti v Ljubljani poskuša vzpostaviti razmere za razvijanje izobraževanja na daljavo kot sodobne in učinkovite oblike izobraževanja. Povezovati poskuša različne akterje pri izobraževanju na daljavo, da bi dosegli večjo prilagodljivost in dostopnost izobraževanja, kakovostnega razvoja in izvajanja študijskih programov. CDED-center za razvoj študija pri Univerzi v Mariboru nudi svetovalne in tehnične storitve s področja odprtega učenja in študija na daljavo vsem pedagoškim delavcem Univerze, po dogovoru pa tudi drugim izobraževalnim ustanovam. Njegova naloga je zagotavljati strokovnost študijskega procesa na daljavo in transformacije učnega gradiva ter skrbeti za kvalitetne tehnične storitve pri izvajanju tovrstnih študijskih programov. Center za daljinsko izobraževanje na Fakulteti za elektrotehniko razvija lastne aplikacije. $V$ sodelovanju s podjetjem Iskratel je bil v okviru centra razvit integrirani sistem za izobraževanje na daljavo, ki se uporablja $v$ različnih ustanovah in podjetjih (Telekom Slovenije, osnovne šole). MIRK, Zavod za projektno in raziskovalno delo na internetu in Zavod za odprto družbo sta $v$ sodelovanju z Ministrstvom za 
šolstvo in šport in Zavodom RS za šolstvo v okviru programa Računalniško opismenjevanje $\vee$ zadnjih nekaj letih izvajala pilotni projekt učenja na daljavo za osnovnošolce in sicer na osnovi uporabe sodobnih IKT. DOBA, Visoka poslovna šola Maribor je samostojen visokošolski zavod, ki izvaja kvaliteten, praktično usmerjen visokošolski strokovni študijski program Poslovni asistent na prvi stopnji, ki je prvi akreditiran visokošolski študijski program $\vee$ severovzhodni Sloveniji na področju poslovnih in upravnih ved, usklajen z Bolonjsko deklaracijo. V Sloveniji je tudi nekaj organizacij, ki se ukvarjajo s spodbujanjem, promocijo in ponudbo programov e-izobraževanja. Ena takšnih organizacij je Javna agencija za podjetništvo in tuje investicije (JAPTI, bivši Pospeševalni center za malo gospodarstvo), ki v sodelovanju z Laboratorijem za telekomunikacije pri Fakulteti za elektrotehniko (LTFE) nudi podporo razvijalcem programov e-izobraževanj. JAPTI zagotavlja tudi usposabljanja za razvijalce, tutorje oz. mentorje. Referenčni centri za e-poslovanje, ki so prav tako mreža, ki so jo razvili JAPTI in nekateri njihovi partnerji, so tudi izdelali nekaj programov eizobraževanja, ki se v največji meri nanašajo na podjetništvo in vsebine, povezane s podjetništvom. V Sloveniji torej imamo interdisciplinarno znanje, potrebno za sistematsko uvedbo e-izobraževanja. Dobre prakse pri uvajanju e-izobraževanja $\checkmark$ slovenski visokošolski sistem obstajajo, dejstvo pa je, da je pri tem potreben sistemski in interdisciplinaren pristop, ki bi zagotovil kar se da enoten sistem uvajanja in izvajanja e-izobraževanja ter spodbujal posameznike $k$ uporabi tega načina pridobivanja znanja na vseh ravneh (formalno, neformalno izobraževanje, izpopolnjevanje, usposabljanje ipd.).

\subsection{Izvajanje e-izobraževanja v visokošolskih institucijah}

Intenzivno uvajanje IKT $\vee$ izobraževalne procese je postalo prioritetna naloga $v$ sodobnih izobraževalnih institucijah povsod po svetu. Nedvomno je prišel čas za uvajanje e-izobraževanja na univerzah, ki se želijo razvijati $v$ nezadržno rastočem globalnem izobraževalnem trgu. E-izobraževanje je izziv in orodje za izboljšanje izobraževalnih procesov in zdi se, da je tudi temelj za nove in bolj učinkovite načine za upravljanje z znanjem.

Uvajanje e-izobraževanja na večjih izobraževalnih institucijah ni lahka naloga. Zahteva širok in interdisciplinaren pristop do organizacije, uvajanja, načrtovanja, infrastrukture, administracije, evalvacije, kakovosti in ekonomike izobraževalnih procesov. Zdi se, da alternative uvajanju e-izobraževanja praktično ni, saj globalni trg znanja ustvarja tekmovalno okolje, kjer bodo tisti, ki bodo izkoriščali prednosti sodobnih IKT, nesporno imeli primerjalno prednost 


\section{Boštjan Požar \\ Razvoj e-izobraževanja in njegova vloga \\ pri razvoju človeških virov}

pred drugimi. V Sloveniji so do danes e-izobraževanje $v$ različnih oblikah uvedle Fakulteta za elektrotehniko, Fakulteta za računalništvo in informatiko, Ekonomska fakulteta, Fakulteta za matematiko in fiziko Univerze v Ljubljani, Fakulteta za organizacijske vede, Fakulteta elektrotehniko, računalništvo in informatiko, Pedagoška fakulteta in Fakulteta za strojništvo Univerze v Mariboru, Fakulteta za management Univerze na Primorskem ter Fakulteta za logistiko Celje-Krško (uporablja portal za e-izobraževanje Univerze v Mariboru).

Kakšna pa sploh je pripravljenost izobraževalnih institucij na e-izobraževanje? $\checkmark$ zimskem semestru 2005/2006 je bila med 85 zavodi terciarnega izobraževanja $\vee$ Slovenji izvedena anketa o e-izobraževanju, na katero je odgovorilo 79 zavodov. Med vsemi 85 zavodi sicer prevladujejo javni zavodi v okviru univerz, kljub temu pa imamo 34 enot terciarnega izobraževanja $v$ organizacijah izven fakultet oziroma univerz, 24 zasebnih in 36 višješolskih zavodov. Ugotovitve:

- Zavodi visoko ocenjujejo neizkoriščeni potencial IKT, saj menijo, da bi intenzivnejša uporaba IKT lahko bistveno izboljšala raziskovalno, pedagoško in poslovno dejavnost; na lestvici 1-5 so vse ocene okoli 4.0. Pri tem izraziteje izstopajo Univerza $\vee$ Mariboru, višješolski in zasebni zavodi. Opazno pa pri tem zaostaja humanistika.

- Da je e-izobraževanje zanje strateškega pomena, ocenjuje tretjina zavodov (povprečje na skali 1-5 je 3.6). Izstopajo predvsem zasebni in višješolski zavodi, izrazito pa zaostaja Univerza $\vee$ Ljubljani in celotna humanistika.

- Zavodi so v splošnem dobro informirani o e-izobraževanju (3.5), kljub temu pa si želijo še več informacij (3.3) in nacionalne koordinacije (3.6). Mnenje, da niso dovolj informirani in da je potrebno več nacionalne koordinacije, izstopa predvsem pri zavodih, ki e-izobraževanja ne postavljajo kot strateško prioriteto.

- Velika večina (93\%) zavodov je že obravnavala e-izobraževanje na sejah kolegija dekana, $18 \%$ zavodov obravnava to temo mesečno in $7 \%$ tedensko. Izstopa Univerza $\vee$ Mariboru, kjer to problematiko mesečno obravnava tretjina (31\%) zavodov.

- Spletno stran z osnovnimi informacijami ima na povprečnem zavodu $70 \%$ vseh predmetov, spletno stran, ki se v toku semestra ažurira, 58\% vseh predmetov, spletno stran, kjer študenti lahko na določen način aktivno sodelujejo $26 \%$ vseh predmetov.

- Razmeroma visok delež predmetov (12\%), ki uporablja virtualno učno okolje (izstopa Moodle), je iz Univerze v Mariboru (16\%) in enot $v$ organizacijah $(21 \%)$, povsod drugje je ta delež pod $5 \%$. Kot običajno na 
področju e-izobraževanja tudi $\vee$ tem pogledu izstopajo zasebni zavodi, višješolski zavodi ter področje ekonomije, delno tudi tehnike.

- Tretjina (30\%) vseh zavodov z e-izobraževanjem že nadomešča (vsaj delno) neposredna srečanja s študenti (predavanja in vaje); največji delež takih zavodov je na Univerzi Mariboru (46\%) in Univerzi na Primorskem (40\%), najmanj pa na Univerzi v Ljubljani (17\%). Med enotami terciarnega izobraževanja pa je ta delež 33\%.

Tabela 1: Rezultati ankete opravljene med visokošolskimi zavodi glede uporabe oz. namena uporabe e-izobraževanja

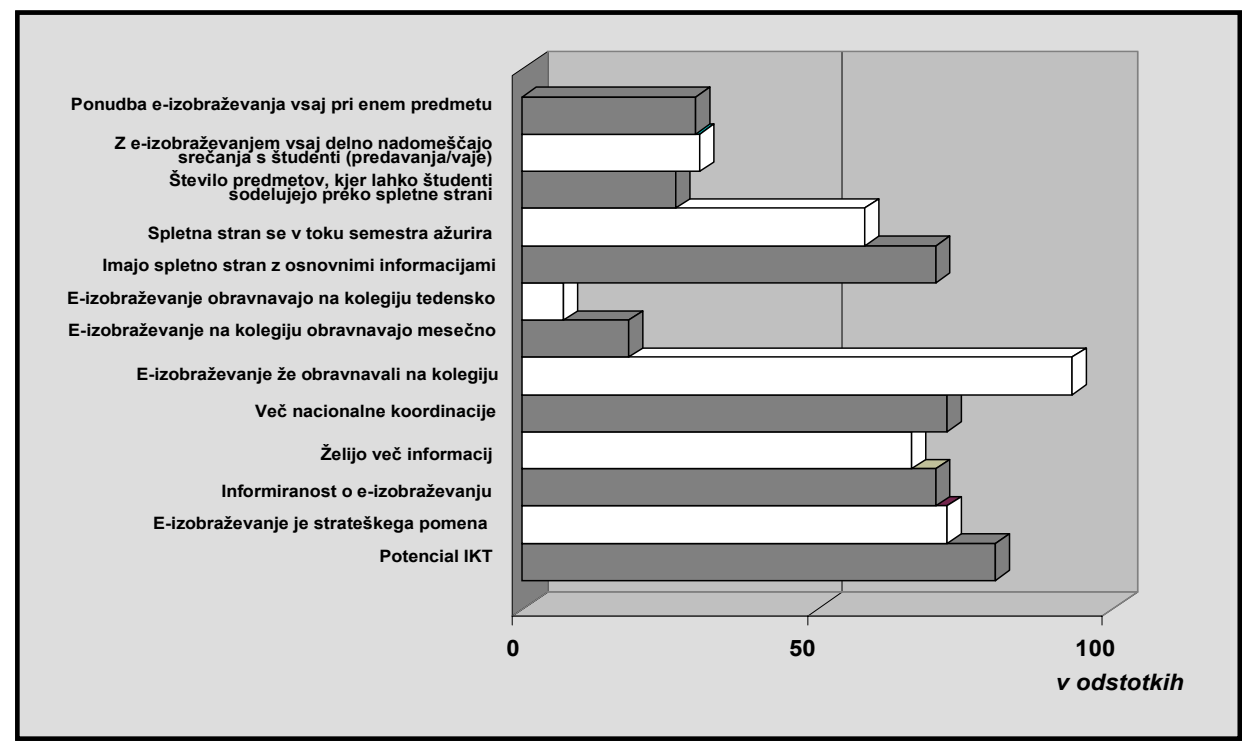

Vir: RIS (Raba interneta v Sloveniji); Interno gradivo Dostopno na: http://www.ris.org/index.php?fl=2\&lact=1\&bid=1293\&avtor=40\&parent $=13$

Zavodov, ki nudijo e-izobraževanje pri vsaj enem predmetu, je 25 (29,4\% vseh zavodov), zavodov, ki nudijo vsaj en študijski program $v$ elektronski obliki, pa je $24(28,2 \%)$. Pri vsaj petih zavodih so prikazani rezultati stanja nekonsistentni oziroma precenjeni (glede na primerjavo z uporabo virtualnega učnega okolja). Zavodov, ki nudijo e-izobraževanje pri določenih predmetih, je 16, zavodov, ki pa so posredovali tudi podatke za študijske programe, je 19. Javni zavodi v povprečju nudijo 6,8 predmetov $\vee$ obliki e-izobraževanja, na zasebnih šolah pa je to povprečje večje (25,5 predmetov). Glede na področje $\vee$ številu predmetov vodi ekonomija z 21 predmeti v obliki e-izobraževanja. Število študijskih programov $\vee$ povprečju glede na vrsto zavodov pa je naslednje: na zasebnih zavodih je povprečno število študijskih programov 2,6, na Univerzi na Primorskem pa 2,5, medtem ko samostojne fakultete, samostojne visoke in višje 


\section{Boštjan Požar \\ Razvoj e-izobraževanja in njegova vloga \\ pri razvoju človeških virov}

šole, študijskih programov $v$ elektronski obliki ne ponujajo. Največji delež zavodov, ki z e-izobraževanjem nadomeščajo neposredne stike s študenti med univerzami, je $\vee$ Mariboru (46\%), nato na Primorskem (40\%), na Univerzi v Ljubljani pa temu področju zaenkrat posvečajo manj pozornosti (le $17 \%$ zavodov na tej Univerzi ima e-izobraževanje). Največji delež zavodov, ki pa o eizobraževanju niso niti razmišljali, je na področju humanistike, morda zato, ker je na teh zavodih študij drugačne narave in se vodstvu zdi učenje na daljavo težje izvedljivo. Po drugi strani pa visoka uporaba virtualnega učnega okolja povsem upravičeno ne pomeni tudi uporabo e-izobraževanja, ki zmanjšuje kontaktne ure. Pregled spletnih strani fakultet, ki naj bi ponujale možnost e-izobraževanja, je pokazal, da so informacije o tem načinu študija izredno skope. Praktično na vseh obravnavanih spletnih straneh o e-izobraževanju ni nikakršnih informacij, zato na ta način ni mogoče ugotoviti, ali e-izobraževanje ponujajo kot samostojni študij ali kot dopolnitev klasičnemu študiju. Lahko rečemo, da je danes ponudba e-izobraževanja $v$ slovenskih visokošolskih institucijah in programih še vedno premalo zastopana, kljub temu, da bi upoštevajoč znanje s katerim visokošolske institucije razpolagajo, lahko pričakovali bistveno bolj razvito ponudbo. Možnost e-izobraževanja na tak ali drugačen način še vedno ponuja relativno majhen delež višje in visokošolskih zavodov $v$ Sloveniji, kar je $v$ primerjavi z gospodarstvom, ki po rabi e-izobraževanja prednjači v evropskem merilu, precej slabo izhodišče za razvoj e-izobraževanja.

\subsubsection{Tehnološko okolje in njegov razvoj}

Okolje za e-izobraževanje mora podpirati shranjevanje, iskanje, indeksiranje, razvrščanje, sestavljanje in dopolnjevanje izdelanih vsebin. Splošno sprejete osnovne funkcionalnosti integriranega elektronskega okolja za e-izobraževanje so (Lockwood et al, 2001): administrativna podpora študentu, elektronska podpora prijavnemu in vpisnemu procesu, podpora osebni in skupinski komunikaciji z elektronsko pošto, upravljanje napredovanja študentov pri osvajanju učne snovi, poročanje in ocenjevanje, upravljanje učnih predmetov skupaj s kreiranjem predmetov, upravljanje dostopa do učnih virov, distribucija učnih gradiv, asinhrona konferenčna komunikacija, sinhrona konferenčna komunikacija, izmenjava dokumentov, zagotavljanje dostopa do spremljajočih storitev, informacijsko podprto testiranje in ocenjevanje. Tehnologija zajema:

- infrastrukturo; internet, intranet in hibridne platforme, pripomočke za delo brez neposredne povezave, uporabniške vmesnike ter možnosti osebne nastavitve dostopa, 
- $\quad$ sisteme za upravljanje izobraževalnih vsebin (learning content management systems) - upravljanje izdelave, objave, sestavljanja, sledenja in distribucije izobraževalnih vsebin,

- sisteme za upravljanje izobraževanja (learning management systems); programe za načrtovanje, dobavo in upravljanje vseh učnih dogodkov ter za vodenje učencev in sledenje njihovemu napredku, tudi možnosti integracije različnih virov in sistemov ipd.

- tehnologije učenja in poučevanja; potek mentorstva, klepetalnice, forumi, vodene diskusije, seminarji, virtualne učilnice ipd.

$\checkmark$ Sloveniji lahko kot primer dobre prakse izobraževalnega portala navedemo portal Itfe.org, ki posameznikom in organizacijam omogoča dostop do izobraževalnih vsebin iz različnih virov ter povezave na strani, povezane z določeno izobraževalno vsebino. LTFE je razvil sistem za e-izobraževanje E$\mathrm{ECHO}$, ki nudi celovito rešitev za podporo e-izobraževanju. Portal deluje $v$ več načinih, uporabniškem in administratorskem. To pomeni, da se posameznik lahko prijavi kot učeči, kot administrator ali kot mentor. Program ob prijavi preverja identiteto uporabnika in na podlagi le-te dodeli pravico dostopa do storitev oz. vsebin. Tehnološko okolje se je tako iz portalov, na katerih so bile dostopne izobraževalne vsebine, razvilo $v$ sisteme $s$ široko paleto storitev, $v$ zadnjem času zlasti z dvosmerno avdio in video komunikacijo med učečim in mentorjem.

\subsubsection{Nove tehnologije kot sestavni del učnega procesa}

Nove tehnologije omogočajo razvoj novih pristopov k izobraževanju in prinašajo določene prednosti in ugodnosti, tako za organizacijo kot za učeče. Najpomembnejši prednosti e-izobraževanja sta prihranek časa in prihranek stroškov, najpomembnejše pomanjkljivosti pa so povezane z načinom podajanja snovi, pri čemer je potrebna velika mera samodiscipline in motivacije učečih, saj gre za hladen in neoseben pristop, potrebna pa je tudi ustrezna informacijska infrastruktura. Klasični modeli učenja ne dohajajo izziva po izobrazbi $\vee$ sodobnem svetu, e-izobraževanje pa ponuja pripomočke za dohajanje tega izziva. Dejstvo je, da e-izobraževanje ne bo nadomestilo predavanj $\vee$ učilnici, ga bo pa nadgradilo z izkoriščanjem prednosti novih vsebin in tehnologij.

Glede na način komuniciranja, ki ga tehnologija dopušča, delimo tehnologijo $v$ grobem na enosmerno asinhrono in dvosmerno sinhrono tehnologijo (Debevc et al, 2003). Tehnologije, ki dopuščajo enosmerno asinhrono komunikacijo so multimedija (avdio, video, animacije, grafika), televizijski in radijski izobraževalni program ter kasete in videokasete. Dvosmerno sinhrono komunikacijo pa 


\section{Boštjan Požar \\ Razvoj e-izobraževanja in njegova vloga \\ pri razvoju človeških virov}

omogočajo interaktivna televizija, satelitski dvosmerni prenos, telekonference in videokonference.

$\checkmark$ letu 2005 je potekala raziskava, $v$ kateri je 73 rednih študentov dodiplomskega študija na Fakulteti za management Univerze na Primorskem ocenjevalo predavanje prek spletne videokonference. Raziskava je obravnavala eno samo predavanje, ki ni bilo vnaprej najavljeno, zato je bil ocenjen tudi učinek prvega vtisa, ki je pomemben $v$ psiholoških raziskavah, saj določa subjektivno sprejemljivost in pričakovanja od nove tehnologije. Rezultati so pokazali, da so študenti zelo sprejemljivi za nove oblike predavanj, saj jim virtualizacija izobraževanja ne dela večjih težav. Zanimivi so bili odgovori, ki so se nanašali na komunikacijo med učiteljem in študenti, kjer tehnologija le stežka nadomešča neposredne stike.

\subsection{Stroški e-izobraževanja}

Stroški so pomemben vidik e-izobraževanja in igrajo ključno vlogo pri ekonomskih odločitvah subjektov, ki se nanašajo na uvajanje in izvajanje eizobraževanja. Izkušnje univerz (Kamtsiou, 2002), ki so že vpeljale e-izobraževanje, kažejo, da so stroški veliki in je pomemben rezultat takega izobraževanja zlasti kakovost izobraževanja, ne pa zmanjšanje stroškov. Navadno financirajo posredovanje učnih gradiv kar izobraževalne institucije, ker je tako izobraževanje $v$ glavnem še vedno dopolnilo klasičnemu programu, nekatere institucije pa že ponujajo e-izobraževanje kot popolno nadomestilo klasičnega izobraževanja. Preden se institucija odloči za izvajanje e-izobraževanja, naj bi pretehtala stroške ( $z$ uporabo modelov o donosnosti naložbe), ki bi ob tem nastali. Ti so: začetni (infrastruktura, oprema in material za ponudbo gradiv), tekoči stroški (npr. podpora informacijski tehnologiji), stroški izdelave in posredovanja učnih gradiv ter stalni in spremenljivi stroški (glede na število študentov). Stroški, povezani z razvojem gradiv, so lahko stalni in se s številom vpisanih študentov oz. s pogostostjo uporabe gradiv ne spreminjajo oz. se preračunano na študenta celo zmanjšujejo, lahko so pa spremenljivi, kar pomeni, da se s povečevanjem števila študentov povečujejo. Izobraževalni proces, še posebej, če je podprt z IKT, se lahko izvaja le ob vnaprej pripravljenih študijskih gradivih, ki se običajno, razen če ne gre za enkratne izvedbe predmetov, uporabljajo pri večjem številu študentov, pri večjem številu izvedb predmeta in več let. Stroškovna učinkovitost z IKT podprtega izobraževanja je odvisna od izbire tehnologije, ki vpliva na strukturo stroškov, predvsem na delež stalnih in spremenljivih stroškov, od števila vpisanih študentov, ki vplivajo predvsem na zniževanje stalnih stroškov na enoto, od obsega kurikuluma, od pogostosti 
ponavljanja izvedb brez sprememb, od obsega gradiv, od splošne uporabnosti gradiv $\vee$ različnih programih, od uporabe brezplačnih oz. avtorsko zaščitenih gradiv (Rumble 2001). Nadalje na stroške vplivajo metode dela (delo $v$ manjših skupinah zahteva večje število mentorjev), obsega in načina zaposlitve pedagoškega in podpornega osebja. Razvoj gradiv je naložba in je višina nastalih stroškov $v$ veliki meri odvisna od uporabljene tehnologije oz. odločitve, na kakšen način se bo izvajalo e-izobraževanje, od katerega je odvisen obseg vloženega dela, ki variira od 1 do 100 vloženih ur za eno pedagoško uro. Stroški e-izobraževanja so pomembni tako z vidika izobraževalne inštitucije kakor tudi z vidika udeleženca. Z razvojem tehnologije, e-izobraževanja, prenosom izkušenj in dobrih praks pa se znižujejo tudi stroški. $V$ času, ko so tudi klasična izobraževanja postala poslovna priložnost, stroški udeleženca e-izobraževanja niso ovira.

\subsection{Potrebe po e-izobraževanju v poslovnem okolju}

Izsledki raziskave, ki je $v$ mesecu marcu 2004 potekala med organizacijami $\checkmark$ Sloveniji (izvajal jo je tedanji PCMG), nudijo vpogled v prakso usposabljanja in izobraževanja zaposlenih ter posnetek trenutnega stanja na področju eizobraževanja. Vzorec: osebe $\vee 2000$ mikro, majhnih, srednjih in velikih gospodarskih subjektih. Glavne ugotovitve raziskave so:

- Približno 40\% zaposlenih $v$ gospodarstvu je imelo $v$ letu 2003 vsaj enkrat plačano kotizacijo za seminar ali delavnico, $v$ negospodarstvu pa znaša ta delež skoraj $75 \%$. Skupini zaposlenih, ki sta bili $\vee$ letu 2003 deležni največjega števila obiskov seminarjev in delavnic, sta skupini strokovnjakov (48\%) ter vodilnih delavcev (32\%). V primeru mikro in malih organizacij je povečan delež obiskov seminarjev in delavnic vodilnih delavcev (40\%) ter zmanjšan delež strokovnjakov (40\%), v primeru srednjih ter velikih organizacij pa je delež vodilnih zmanjšan (16\%), povečan pa je delež strokovnjakov (60\%).

- Vodstvo je dokaj naklonjeno procesu usposabljanja in izobraževanja; povprečna vrednost odgovorov na lestvici od 1 do 5 znaša 3,83.

- Največji vpliv pri odločanju o obiskih seminarjev in delavnic ima vodstvo organizacij $(4,42)$; vpliv zaposlenih je manjši (povprečna vrednost odgovorov znaša 3,44$)$. 


\section{Boštjan Požar \\ Razvoj e-izobraževanja in njegova vloga \\ pri razvoju človeških virov}

- Odsotnost zaposlenih je z različnih vidikov $v$ splošnem neproblematična (vrednosti nižje od 3, pri čemer najvišjo $(2,90)$ dosega vidik nenadomestljivosti zaposlenega zaradi njegovih znanj in sposobnosti).

- Najpomembnejši prednosti e-izobraževanja sta po mnenju vprašanih prihranek časa in prihranek stroškov potovanj, najpomembnejše pomanjkljivosti pa so povezane $\mathrm{z}$ načinom podajanja snovi ter ustrezno informacijsko infrastrukturo.

- V gospodarstvu so za e-izobraževanje najbolj primerna področja financ, računovodstva, gospodarskega prava ter poslovanje z EU. $V$ negospodarstvu pa so poleg financ in računovodstva po mnenju vprašanih primerna še javna naročila in znanja s področja uporabe računalniških programov.

- Namero po uporabi metode e-izobraževanja $v$ prihodnjih treh letih; gospodarstvo (3.04), negospodarstvo (2.6), obe vrednosti pa nakazujeta zadržanost glede uporabe e-izobraževanja.

- Več kot tri četrtine vprašanih meni, da je na trgu premalo informacij o eizobraževanju.

- V $5 \%$ organizacij so se že usposabljali in izobraževali po metodi eizobraževanja, pri čemer je bila $\vee 42 \%$ odstotkih vsebina posredovana od domačega ponudnika e-izobraževanja, $\vee 46 \%$ pa od tujega; $12 \%$ organizacij ima lasten sistem e-izobraževanja. Sicer ima skoraj polovica uporabnikov pozitivne izkušnje z metodo e-izobraževanja.

Slovenija ima uporabo e-aplikacij za izobraževanje zaposlenih (vsa podjetja z 10 ali več zaposlenimi, izvzet finančni sektor) v primerjavi z drugimi državami $\checkmark$ Evropski uniji zelo razširjeno. $\vee$ Sloveniji uporablja e-izobraževanje $40 \%$ podjetij, kar jo uvršča na tretje mesto, za Litvo in Ciprom. Delež takšnih podjetij se je od leta 2004 tudi povečal za 10 odstotnih točk. Slovenija na področju eizobraževanja sicer v letu 2005 ni dosegla večjega napredka pri uporabi interneta $\vee$ namene dodatnega izobraževanja. Delež uporabnikov, ki internet uporabljajo za tečaje $\vee$ povezavi z zaposlitvijo, se je $\vee$ primerjavi z letom 2004 povečal za zanemarljivo 0,1 odstotne točke, delež uporabnikov, ki internet uporabljajo za tečaje izpopolnjevanja, pa za 0,9 odstotne točke. Večji napredek je bil na področju formalne izobrazbe, kjer se je delež povečal za 7,3 odstotne točke. Eden izmed pomembnejših vzrokov za povečanje je verjetno posledica tega, da se formalno $\vee$ večji meri izobražujejo mlajši ljudje, ki so bolj dovzetni za IKT. 
Tabela 2: Rezultati ankete opravljene med podjetji v Sloveniji glede uporabe oz. namena uporabe e-izobraževanja

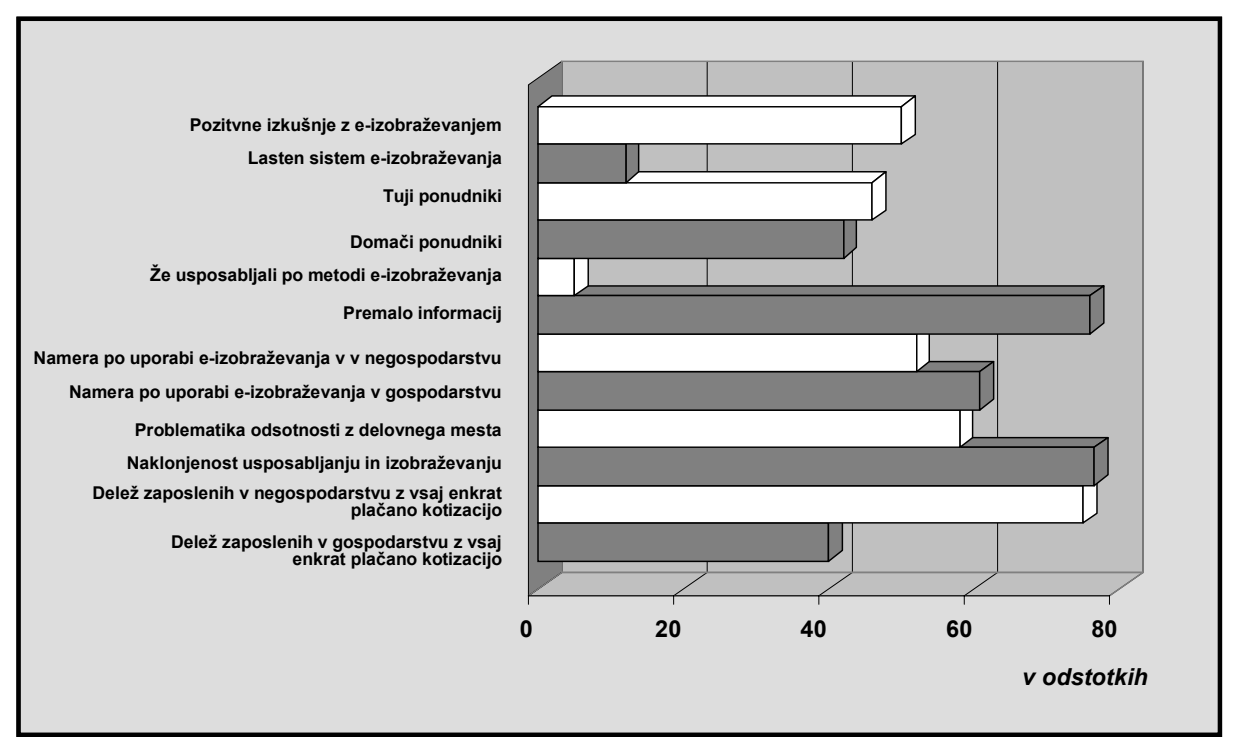

Vir: JAPTI (bivši PCMG); Interno gradivo

Reprezentativna telefonska anketa RIS 2005, ki nadaljuje standardne ankete RIS od 1996, je bila izvedena med 713 slovenskimi podjetji v juniju 2005. Odgovarjali so vodje informatike ali direktorji. Povzetek je naslednji:

- Delež podjetij, ki so $\vee$ preteklem letu svoje zaposlene poslala na kakršenkoli izobraževalni tečaj, znaša za velika podjetja $88 \%$, za srednja $83 \%$, za majhna $71 \%$ ter za mikro 44\%;

- Med zaposlenimi $\vee$ velikih podjetjih se jih je $\vee$ preteklih 12 mesecih formalno izobraževalo $9 \%$. Ta delež narašča z manjšanjem velikostne kategorije podjetij in doseže za mikro podjetja 16\%. Za vsa podjetja (vzorec) znaša delež $11 \%$, utežen na populacijo pa $16 \%$;

- Med zaposlenimi v slovenskih podjetjih je okoli odstotek takih, ki so se v preteklem letu izobraževali v tujini;

- Delež podjetij, ki pojem e-izobraževanja poznajo, je najvišji med velikimi podjetji (76\%), najmanjši pa pri mikro podjetjih (41\%). Med podjetji v vzorcu je približno petina e-izobraževanje že uporabljala;

- Med zaposlenimi, ki so se $\vee$ preteklem letu izobraževali, se jih je $\vee$ programih e-izobraževanja izobraževalo $10 \%$ ( $2 \%$ v velikih, $28 \% \vee$ malih). $\vee$ 
Boštjan Požar

\section{Razvoj e-izobraževanja in njegova vloga pri razvoju človeških virov}

preteklem letu se je e-izobraževalo okoli 1\% vseh zaposlenih v slovenskih podjetjih;

- Čeprav je le relativno nizek delež podjetij že uporabljal e-izobraževanje (deleži se gibljejo okrog 15\%), pa zanimanje približno trikrat presega uporabo;

- Dodati velja, da če podjetja vprašamo neposredno po internem eizobraževanju in po on-line gradivu v okviru intraneta, o tem poroča $43 \%$ velikih in okrog petina srednjih, majhnih in mikro podjetij;

- Podjetja, ki so zaposlene že e-izobraževala, poročajo, da e-izobraževanje uporabljajo predvsem za področje računalništva in informatike;

- $\quad$ Nobeno od podjetij, ki z e-izobraževanjem že imajo izkušnje, ne poroča nezadovoljstva s tem načinom izobraževanja. Povprečna ocena zadovoljstva na lestvici od 1 do 5 je 3,6;

- Podjetja se v veliki meri strinjajo $(4,0)$, da imajo njihovi zaposleni raje klasično kot pa e-izobraževanje ter da je pri e-izobraževanju privlačna predvsem fleksibilnost.

Tabela 3: Rezultati ankete RIS glede uporabe e-izobraževanja

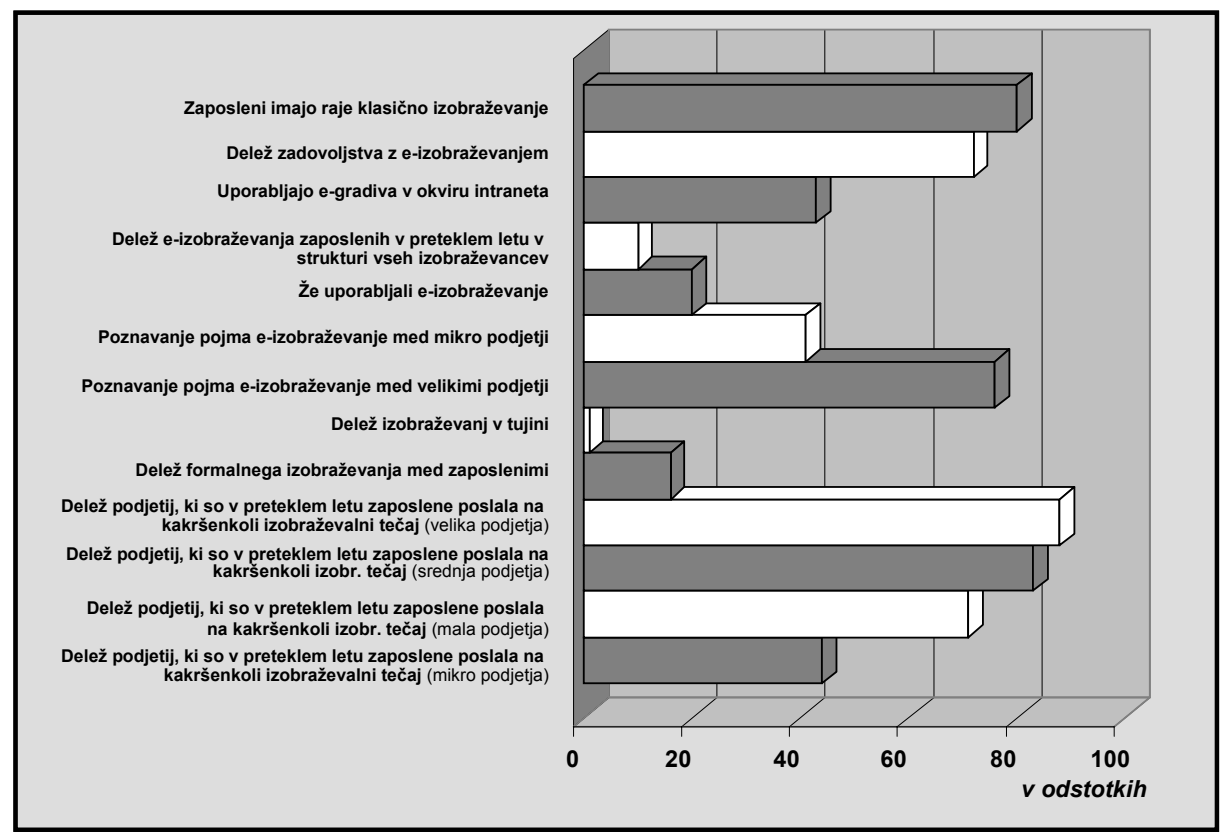

Vir:RIS (Raba interneta v Sloveniji); Interno gradivo; Dostopno na: http://www.ris.org/index.php?fl=2\&lact=1\&bid=946\&parent $=13$ 


\subsection{Dejavniki, ki vplivajo na odločitev za vključitev v e-izobraževalni program}

\subsubsection{Motivacija}

Motivacija je psihološko stanje posameznika, usmerjeno k izpolnitvi določene potrebe. Pri e-izobraževanju je motivacija eden ključnih dejavnikov, ki vplivajo na uspešnost e-izobraževanja, saj mora biti posameznik dovolj motiviran, da je udeležen $v$ procesu e-izobraževanja, $v$ katerem samostojno sodeluje, pridobiva informacije, vire in uporablja razpoložljiva učna orodja. Dokazano je, da visoko motivirani ljudje dosegajo rezultate, za katere vsi drugi trdijo, da so nemogoči. Rezultati raziskav so pokazali, da imajo lastni motivi večji pomen pri motiviranju zaposlenih kot brezposelnih. Stališča, ki najbolj motivirajo anketirance, so povezana predvsem z izboljšanjem ekonomskega položaja posameznika. Presenetljivo je, da so taka stališča veliko bolj izražena pri zaposlenih kot pri brezposelnih. Pri motivaciji igra pri e-izobraževanju pomembno vlogo mentor ali tutor, kot ga pogosto imenujejo, ki mora odigrati poleg strokovne vloge tudi vlogo motivatorja. Ni več neposrednega osebnega stika med samimi udeleženci in s predavateljem. Učna vsebina ni več vezana na predavatelja, ampak nastopa samostojno in stoji in deluje sama po sebi. Vsebina celo prevzame del predavateljevih nalog. Glavni nalogi mentorja v e-izobraževanju sta tako zagotavljanje učne in motivacijske podpore udeležencem ter vrednotenje odgovorov in nalog udeležencev. Glavna naloga udeleženca eizobraževanja pa ostaja enaka kot v klasični obliki, to je osvojitev čim več uporabnega znanja in spretnosti ter osebnostna rast in razvoj. Poleg osebnih izzivov, radovednosti ter potrebe po kompetentnosti in dosežkih pa na motivacijo močno vpliva tudi pomen oziroma vloga izobraževanja pri naših dolgoročnih ciljih. $V$ vsakem primeru mora učeči imeti razlog, ki ga dovolj motivira, da vztraja pri e-izobraževanju, ki je neosebno že po definiciji. Kljub temu, da je učeči vendarle $v$ stiku s svojim mentorjem, se mora spopasti s pripravljenostjo porabiti svoj čas za računalnikom. Pri e-izobraževanju je motivacija ključnega pomena za uspešnost izobraževanja, zato ta način za nemotivirane posameznike ni najbolj primeren.

\subsubsection{Tehnološke možnosti}

Odločitev o vključitvi v e-izobraževanje je pogojena tudi s tehnološkimi možnostmi posameznika. Za uspešno udeležbo $v$ programu e-izobraževanja je 


\section{Boštjan Požar \\ Razvoj e-izobraževanja in njegova vloga \\ pri razvoju človeških virov}

potreben povprečno zmogljiv računalnik z ustrezno programsko opremo, ki omogoča pregledovanje pripravljenih učnih gradiv in drugih vsebin. Glede na to, da je velik del gradiv $\vee$ obliki HTML, udeleženec potrebuje običajen spletni brskalnik. Lahko pa so učna gradiva pripravljena $\vee$ drugih formatih kot so ppt, doc, pdf, jpg, flash, java in drugi. $V$ tem primeru je potrebna ustrezna programska podpora, ki podpira navedene formate, novejše inačice programske opreme pa bodo zagotovile, da bo učeči datoteko z učno snovjo z gotovostjo odprl. Pri e-izobraževanju je pomembna tudi hitrost povezave do interneta. Počasne internetne povezave otežujejo e-učenje. Ob znižanju cene in širšemu preboju hitrejših povezav (ADSL) v preteklem letu, prenos podatkov ne pomeni več tistih ovir, ki bi lahko ključno vplivale na odločitev posameznika o vključitvi $\checkmark$ e-izobraževanje. Reprezentativna telefonska anketa RIS ( $n=3.400)$, izvedena decembra 2004, kaže, da ima okoli 55\% oseb (935.000) v starosti od 10 do 75 let oz. 52\% slovenskih gospodinjstev (355.000) dostop do interneta. Pri tem je glavni dostop skoraj vedno dostop z osebnim računalnikom. $V$ splošnem beležimo med gospodinjstvi hitro širitev dostopa do interneta, saj je $v$ letu dni internet vstopil v skoraj $10 \%$ novih slovenskih gospodinjstev. Slovenija se je s tem povsem približala povprečju državam EU15 oziroma ga je presegla, če upoštevamo tudi mobilni dostop. Tudi navedeno govori $v$ prid trditvi, da glede na rabo IKT tehnologija ni več ključna ovira e-izobraževanju.

\subsubsection{Računalniška pismenost}

E-izobraževanje sicer ne zahteva naprednih računalniških znanj, vendarle pa je to za posameznika, ki mu spopadanje z računalniškimi veščinami predstavlja problem, lahko odločilen dejavnik. Dandanes so osnovna računalniška znanja nuja za delo na številnih delovnih mestih, saj je računalnik $v$ veliki meri prisoten tudi pri opravljanju fizičnih del. Zaradi dviga tehnološke razvitosti $v$ splošnem, je računalniška pismenost ključnega pomena za posameznika, ki želi biti konkurenčen na trgu delovne sile. Računalniško pismenost spodbujata tako Slovenija kot EU vse od osnovne šole pa do tretje generacije (vseživljenjsko učenje). Ekonomske in družbene spremembe namreč spreminjajo značilnosti temeljnih spretnosti, ki omogočajo delovanje $v$ delovnem, družinskem in družbenem življenju. O tem govori Memorandum o vseživljenjskem učenju (2000), ki v prvem ključnem sporočilu določa informacijsko pismenost kot eno od novih temeljnih spretnosti, ki je potrebna za aktivno sodelovanje $\vee$ družbi znanja. $V$ Sloveniji je $\vee$ nekaterih slovenskih regijah nizka raven splošne informacijske pismenosti, še posebej z vidika uporabe računalniških aplikacij. Mednarodne pa tudi domače izkušnje nakazujejo, da je npr. spričevalo ECDL prezahtevno za 
tisti del prebivalstva, ki ni bil deležen računalniškega izobraževanja med rednim šolanjem in nima možnosti uporabe računalnika doma ali na delovnem mestu. $V$ to skupino spadajo predvsem starejši odrasli (starejši od 40 let), odrasli brez izobrazbe in poklica, torej tisti, ki so najbolj ogroženi pri pridobivanju ključnih sposobnosti, ki bi jim omogočale pridobiti ali ohraniti zaposlitev. Po statističnih podatkih je $\vee$ Sloveniji kar 169.000 odraslih z osnovnošolsko izobrazbo ali manj (SURS, 2003), ki so možni iskalci osnovnih računalniških znanj. Na potrebe po osnovnem računalniškem usposabljanju kažejo tudi podatki Zavod RS za zaposlovanje, ki je $\vee$ letu 2002 napotil na računalniške tečaje 1.427 brezposelnih oseb, kar pomeni 49,7 \% vseh vključenih v programe izpopolnjevanja in usposabljanja. Iz teh podatkov sicer ni razvidna razmejitev deležev med napotitvami v osnovno ali specialistično računalniško izobraževanje, kljub vsemu pa je potreba po takem znanju očitna.

Tudi raziskava RIS je pokazala, da se respondenti v veliki meri strinjajo $s$ tem, da se je vse življenje potrebno izobraževati in izpopolnjevati. Leta 2002 kot tudi 2004 so se respondenti najbolj strinjali s trditvijo "vse življenje se je potrebno izobraževati" (4.7) in "pripravljen sem se dodatno izobraževati in izpopolnjevati" (4.4). Leta 2004 (3.5) so se nekoliko bolj kot leta 2002 (3.3) strinjali, da je izobrazba, pridobljena s študijem na daljavo, enakovredna izobrazbi, pridobljeni na klasičen način. Razvijanje sposobnosti in znanj je neprekinjen proces, ki se ne konča z zaključkom formalnega izobraževanja posameznika. Vseživljenjsko izobraževanje pa postaja nujnost, katere uresničevanje spodbuja in podpira tehnologija. Glede na rezultate raziskave in dejstvo, da za vključitev v e-izobraževanje zadostujejo povprečna, skoraj minimalna računalniška znanja, je odločitev posameznika, da se v e-izobraževanje ne bo vključil, verjetno bolj posledica strahu pred novim izzivom kot dejanskega pomanjkanja računalniške pismenosti. Primerjalno s preteklimi leti pa računalniška pismenost očitno tudi napreduje.

\section{Zaključki}

Ponudba e-izobraževanja $v$ Sloveniji se bogati, predvsem $\vee$ sektorju gospodarstva, ki uporablja ta način za razvoj kadrov in posredovanje specifičnih znanj. Obstaja večje število komercialnih ponudnikov programov e-izobraževanja, ki se ukvarjajo s ponudbo e-izobraževanja profesionalno. Fakultete, višješolski in visokošolski zavodi nekoliko zaostajajo pri uvajanju e-izobraževanja in zagotavljajo o tem bistveno premalo informacij. Institucije znanja bi morale biti protagonisti uvajanja e-izobraževanja pri razvoju, raziskovanju in uvajanju. Stroški e-izobraževanja nastajajo pri različnih nosilcih, od stroškov razvijanja aplikacij, stroškov priprave 


\section{Boštjan Požar \\ Razvoj e-izobraževanja in njegova vloga \\ pri razvoju človeških virov}

učnih gradiv, stroškov mentorstva, stroškov udeleženca. Stroški razvijanja aplikacije so veliki, vendar za razvoj e-izobraževanja to ni bistvenega pomena, saj ponudnik lahko že razvito aplikacijo kupi ali najame in s tem veliko prihrani. Stroški priprave učnih gradiv zahtevajo interdisciplinarni pristop, saj je treba angažirati strokovnjake $s$ posameznih strokovnih področij, andragoške strokovnjake (didaktika) in pa računalniške strokovnjake za tehnično izvedbo. Tudi $\vee$ tem primeru obstajajo že pripravljena gradiva drugih ponudnikov, kar lahko prav tako prispeva $k$ znižanju stroškov. Med stroške ponudnika pa štejemo še stroške mentorstva, ki so odvisni od velikosti skupine ter potreb skupine po mentorskem delu. Stroški udeleženca pa so stroški udeležbe ter stroški interneta. Stroški ne bi smeli biti ključna ovira razvoju e-izobraževanja, saj so na udeleženca nižji kot pri klasičnem izobraževanju, ponudniki pa lahko razvite programe, ki so sicer dragi, tržijo dolgo po prvi uvedbi in za veliko število uporabnikov. Tehnološki razvoj omogoča učinkovito izvajanje in razvoj eizobraževanja, razvoj pa gre predvsem $v$ smeri dvosmerne komunikacije (avdio in video povezava). Poslovno okolje $\vee$ veliki meri že uporablja to možnost izobraževanja za zaposlene (Slovenija je pri tem $v$ samem vrhu), v kolikor pa ne, je bila $\vee$ opravljenih anketah izražena velika mera pripravljenosti, da bodo eizobraževanje pri razvoju človeških virov uporabili $\vee$ prihodnje. Motivacija udeleženca je bila na področju individualnih razlogov opredeljena kot ključni dejavnik. Metoda je primerna za visoko motivirane posameznike, ki imajo motiv in jasen cilj, saj je $v$ tem primeru potrebna samostojnost udeleženca pri študiju in lastna organiziranost, da bi posameznik lahko zmogel študijske obveznosti in zahteve, glede na neosebno podajanje znanja. Tehnološka opremljenost potencialnih udeležencev je bila ocenjena kot ustrezna, saj je Slovenija po rabi interneta $v$ samem vrhu $v$ EU, iz česar lahko zaključimo, da je opremljenost z računalniško opremo na ustreznem nivoju. Računalniška pismenost $v$ nekaterih regijah nazaduje, vendar pa e-izobraževanje ne zahteva naprednih računalniških znanj, kar pomeni, da bi se lahko e-izobraževanja udeležil vsak, ki razpolaga z minimalnim poznavanjem delovanja strojne in programske opreme. Bolj kot računalniško neznanje je pri tem pomemben dejavnik strah posameznikov, da ne bi zmogli obvladovati tega izziva. Sociološki dejavniki vsak na svoj način vplivajo na vključevanje v e-izobraževanje; bolj pasivni posamezniki, ki se težje učijo, praviloma potrebujejo kontakt s kolegi in profesorji, zato zanje e-izobraževanje ni primeren način izobraževanja. Privatizacija oz. komercializacija šolstva ter socialne stiske bodo zmanjšale možnosti in želje posameznikov po klasičnem študentskem življenju, kar bi lahko vplivalo na vključevanje posameznikov $\vee$ eizobraževanje. 
Zaključimo lahko, da je e-izobraževanje $v$ Sloveniji $\vee$ splošnem povprečno razvito ( $v$ različnih sektorjih različno, nekje tudi nad povprečjem) in bo na nekaterih segmentih potrebovalo večja razvojna prizadevanja, več informacij in boljšo promocijo, kar naj bi spodbudilo rabo e-izobraževanja. $V$ dobi znanja, $v$ kateri smo se znašli, se naše razumevanje tega, kaj je učenje, kje in kako poteka in za katere namene, spreminja. Vedno bolj pričakujemo, da se bodo metode poučevanja, učenja in same okoliščine učenja prilagodile različnim interesom, potrebam in zahtevam, ne samo posameznikov, temveč tudi posebnih interesnih skupin $v$ multikulturni evropski družbi. To pa pomeni izrazit premik $k$ uporabniku. IKT torej pomeni velike priložnosti za inovacije $v$ metodah poučevanja in učenja. Kljub temu ugotavljamo, da e-izobraževanje še ni v celoti odigralo svoje vloge in še ni udejanjilo vseh svojih zmožnosti.

Boštjan Požar je po zaključenem višješolskem študiju lesarstva diplomiral na Fakulteti za upravo, kjer v tem letu zaključuje magistrski študij. Tako diplomsko kot magistrsko delo obravnavata vprašanja s področja regionalnega razvoja. Zaposlen je na Regionalni razvojni agenciji, kjer dela kot svetovalec. Ima bogate izkušnje z delom na projektih. Je eden izmed soavtorjev RRP Notranjsko-kraške regije 2000-2006, kot sekretar in koordinator priprave RRP pa je aktivno sodeloval tudi pri pripravi RRP Notranjsko-kraške regije za programsko obdobje 2007-2013. 


\section{Boštjan Požar \\ Razvoj e-izobraževanja in njegova vloga \\ pri razvoju človeških virov}

\section{Literatura in viri}

- Dinevski, D. (2003): Informacijska tehnologija v univerzitetnem izobraževanju (Information technology platform for e-learning implementation). V: Društvo i tehnologija 2003. Zagreb: Hrvatsko komunikološko društvo, str. 148-158.

- Lesjak, D., Sulčič, V. (2003): Ekonomski vidiki utemeljevanje projektov e-poslovanja. V: Zbornik posvetovanja / Dnevi slovenske informatike 2003, Portorož, Slovenija, 16-18. april 2003, str. 26-31.

- $\quad$ Dinevski, D., Ojsteršek, M. (2003); Tehnologija in organizacija storitev eizobraževanja. V: Vzgoja in izobraževanje v informacijski družbi. Kranj, Moderna organizacija, str. 538-544.

- Sulčič V., Lesjak D. in A. Balde. (2004): Uvod v ekonomiko e-izobraževanja (Introduction in Economics of e-Learning). Delovni zvezek 10: str. 1-16. Koper, Fakulteta za management.

- Dobnik N. (2001): Pomen izobraževanja na daljavo za gospodarstvo. V: Andragoška spoznanja - Izobraževalni management (tematska številka), letn. 7, št. 4., str. 56-60.

- Dobnik N. (2003): Slovenija pred didaktičnimi izzivi virtualnega učnega okolja. V zborniku: E-izobraževanje doživeti in izpeljati. Maribor, Doba, str. 55-67.

- Geder, M. (2003): Principi oblikovanja modelov e-izobraževanja in njihovo uvajanje v prakso. V zborniku: Strokovna konferenca E-izobraževanje doživeti in izpeljati. Maribor, Doba, str. 121-136.

- $\quad$ Cergol, S. (2003): Participacija, komunikacija in kolaboracija v e-izobraževanju - ali novi mediji omogočajo optimalno in potencialno učinkovito učenje? V zborniku: Strokovna konferenca E-izobraževanje doživeti in izpeljati. Maribor, Doba, str. 107-119.

- $\quad$ Bregar, L. (1998): Študij na daljavo-nove poti komuniciranja v procesu izobraževanja. $\vee$ publikaciji: Vloge in naloge pomočnikov ravnateljev $\vee$ šolskem managementu / I. strokovni posvet Management v izobraževanju, Portorož, 7. 4. do 9. 4. 1997. - Ljubljana: Šola za ravnatelje, 1998. str. 93-121.

- $\quad$ Borger, R. (2000): Psihologija učenja. Ljubljana, Cankarjeva založba. 220 str.

- Kragelj, S. (2002): Gospodarski vestnik, Konferenca Izobraževalni management, Ljubljana.

- Rowntree, D. (1992): Exploring open and distance learning. London: Kogan Page, 299 str.

- RIS, E-izobraževanje 2005/2006, Visokošolski in višješolski zavodi. Dostopno na http://www.ris.org

- RIS, http://www.ris.org/index.php?f|=0\&p1=276\&p2=285\&p3=\&id=288

- $\quad$ RIS, Raziskava rabe interneta v Sloveniji. Dostopno na http://www.ris.org 
- Vesel, P. (2004): Analiza potreb po e-učenju. V publikaciji: EIC novice. str. 18.

- Vehovar, V., Platinovšek, R. (2005): RIS, E-izobraževanje - podjetja. Ljubljana, Center za metodologijo in informatiko - Fakulteta za družbene vede, Univerza v Ljubljani.

- Stanič, M., Macedoni, K. (2004): Evalvacija e-izobraževanja, Strokovno Gradivo Konference Izobraževalni Management, letnik 2, številka 6.

- $\quad$ LTFE, E-CHO sistem za e-izobraževanje, Uporabniški priročnik, verzija 2.4.0.

- JAPTI, Predstavitev dobrih ePraks 2005-2006, 2005-2006.

- Pečnik, T. (2005): E-izobraževanje kot alternativna oblika izobraževanja zaposlenih. Fakulteta za družbene vede, Univerza v Ljubljani, diplomsko delo. 80 str.

- Komisija Evropske skupnosti, Memorandum o vseživljenjskem učenju.

- $\quad$ Nekrep, A. (2000): E-Izobraževanje v programih stalnega strokovnega spopolnjevanja, diplomsko delo. Pedagoška fakulteta Maribor, 93 str.

- Sulčič, V. (2000): Vpliv informacijske tehnologije na izvajanje študija na daljavo, raziskovalno poročilo, ločeno oštevilčenje. Maribor, Ekonomsko-poslovna fakulteta. 
Boštjan Požar

Razvoj e-izobraževanja in njegova vloga

pri razvoju človeških virov

\section{SUMMARY \\ DEVELOPIMENT OF E-EDUCATION AND ITS ROLE IN HUMAN RESOURCES DEVELOPMENT}

In the dynamic times we live in, formally acquired knowledge quickly goes out of date. Lack of adequately trained and educated personnel requires organisations to ensure systematic training and education of personnel. Due to the development of information and communication technologies together with globalisation, companies today face major challenges. These challenges result from changes in demographics as well as the economy. An important common denominator in all of the consequences of these changes is the ongoing requirement for new knowledge, defined as the key factor of any modern organisation's competitiveness. This article defines the options companies have at their disposal, how the economy handles these knowledge requirements, how it responds to the possibilities of new education and the various potentials these methods have. The author has given primary attention to the introduction and use of alternative education options, including, among others, e-education. The following sections of the article focus on the development of e-education, the situation in the field of e-education today, and on providing an answer to the following questions: To what extent is e-education gaining ground as an educational method; and to what extent can e-education replace traditional education in the lecture rooms of tomorrow? It presents an overview of the e-education programme offer in Slovenia; the introduction of e-education into higher education programmes; technological development programmes and related options; e-education preparation and implementation; an analysis of the needs for e-education in the business environment; and other factors that have an impact on an individual's decision to participate in an e-education programme.

The e-education offer in Slovenia is developing briskly, especially in the business sector, which employs this form of education in personnel development and in the transfer of specific knowledge. There are several commercial providers of e-education programmes engaged professionally in providing e-education. Faculties, higher vocational and university level institutes lag behind somewhat in the introduction of e-education and provide far too little information on the subject. Educational institutions should be the main protagonists in the introduction of e-education in development, research and training. E-education costs are incurred by various parties, 
in the form of application development costs, the preparation of study materials, mentorship and participant costs. Application development costs are high, but this is of no consequence for e-education development, as a provider may purchase or lease a previously developed application, and in the process enjoy significant savings. The cost of preparing study materials requires an interdisciplinary approach, as experts from specific professional fields need to be engaged, such as andragogy experts (didactics) and computing experts for technical execution. This case too affords the possibility of acquiring study materials previously prepared by other providers, which can also contribute reducing costs. In addition, provider costs also include mentorship costs which depend on group sizes and the need for work with a mentor. Participant costs include participation and internet costs. Costs should not constitute a key impediment to the development of e-education, as per-participant costs are lower than those incurred in traditional education, and providers may continue marketing otherwise expensive, previously-developed programmes long after their initial introduction, to a large number of users. Technological development enables efficient implementation and development of e-education, which is generally realised in terms of two-way communication (audio and video connection). The business environment already makes use of this option for its employees to a large extent (Slovenia is, in this sense, at the very top of the scale); if this method is not already use, we nevertheless find a considerable willingness to begin using e-education in human resources development in the future in all of the conducted surveys. Participant motivation was defined as the key factor as regards individual motives. This method is appropriate for highly-motivated individuals who have a motive and a clear objective, as in e-education the participant's independence as regards studies and personal organisation are necessary in order for them to successfully carry out their study obligations and requirements, as the process represents a comparatively impersonal manner of imparting knowledge. Technical (computer) equipment of potential participants was deemed adequate, as internet use in Slovenia ranks with the best in the EU. Computer literacy in some regions may be found lagging somewhat, but e-education does not require advanced computer skills, which means that anyone having minimum fluency in computer hardware and software could partake of eeducation. More important than a shortcoming in computer fluency is the fear of not being able to meet such a challenge overall that is an important factor. Sociological factors, each in their own way, have an impact on the 


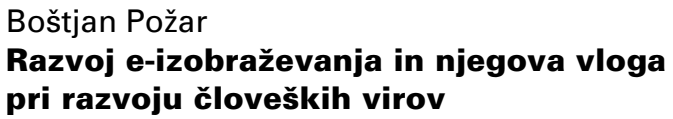

decision to participate in e-education; characteristically passive individuals have more difficulty studying generally require contact with colleagues and teachers, making e-education an inappropriate form of education for them. The privatisation and commercialisation of schooling, together with social hardships, reduce the individual's possibilities for and desire of a traditional student lifestyle, which could positively influence their decision to partake in e-education.

The author concludes that e-education in Slovenia is, overall, at some average level (varying from sector to sector, and above average in some) and that in some segments, requires more significant development efforts, more information and better marketing aimed at encouraging participation in e-education. In the age of information and education in which we live, our perception of learning - what it is, where and how it takes place, and to what end - is changing. Our expectations of education, as well as our need for learning methods and conditions to adapt to a variety of interests, needs and requirements of both individuals as well as special interest groups in a multicultural Europe, continue to grow. It would, however, be inappropriate to claim that e-education will entirely replace traditional education and result in empty lecture rooms. Several factors support this thesis, such as the unsuitability of specific subjects or content for electronic transfer, the difficulty of introducing e-education into higher education institutions, limited technical skills, high learner motivation, and the need for physical contact between students, for group study work and help among others. On the other hand, rapid development of e-education points to the increasingly important role of e-education in existing education programmes. 